
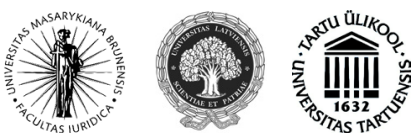

ISSN 1392-6195 (print) ISSN 2029-2058 (online) JURISPRUDENCIJA JURISPRUDENCE 2014, 21(2), p. 335-354.

\title{
THE UN-NATO COOPERATION IN IMPLEMENTING THE UNITED NATIONS SECURITY COUNCIL RESOLUTION 1540
}

\author{
Dalia Vitkauskaitè-Meurice \\ Mykolas Romeris University, Faculty of Law, \\ Institute of International and European Union Law \\ Ateities str. 20, LT-08303, Vilnius, Lithuania \\ Tel.: (+370 5) 2714669 \\ E-mail: dvitka@mruni.eu
}

Submitted on 3 April, 2014; accepted on 25 May, 2014

doi:10.13165/JUR-14-21-2-01

\section{Introduction}

The attacks of September 11, 2001 redefined the concept of nuclear security. It was clear that actors were operating without borders, acts were increasingly more brutal and that there was no limit to the willingness and desire to cause harm. Radioactive material could potentially be a tool used for malicious purposes. In this new light, the need to secure vulnerable material, wherever used, stored or transported, was urgent. Equally, a new framework for nuclear security had to be defined. So, basically once one is talking about nuclear security, the threat comprises of 3 actions: a) theft of nuclear material, including that used in nuclear weapons and for use in improvised explosive devices; $b$ ) theft of other radioactive material for use in radiological dispersal devices; and c) sabotage of nuclear installations or transport. For those very reasons primary responsibility falls under the shoulders of the state if the state does not recognize the threat of nuclear terrorism; the state that does not

Jurisprudencija/Jurisprudence

(C) Mykolo Romerio universitetas, 2014

(C) Mykolas Romeris University, 2014
ISSN 1392-6195 (print), ISSN 2029-2058 (online) http://www.mruni.eu/lt/mokslo_darbai/jurisprudencija/ http://www.mruni.eu/en/mokslo_darbai/jurisprudencija/ 
take preventive action and finally the state that is complacent ${ }^{1}$. Security of nuclear material, in particular high enriched uranium (HEU) and plutonium has always been a priority of the international community. Yet, the context of security was different in the past. It was assumed that radioactive material was self-protecting, in that the radioactivity itself would act as a deterrent and in that the use of material in terrorist acts was beyond the scope of possibility for any person. International terrorism indicated the need to unite efforts in the fight that implies international and national obligations to the states as well as international and regional organisations. While the fight against terrorism implies obligations on states to penalize certain activities and to create a large net of institutions working in political level, the universal legal background concerning the fight of terrorism is primarily attributed to the United Nations (hereinafter - the United Nations or the UN) decision making institutions according to Resolution 1540.

Rather recently terrorism has been recognised as international threat to peace and security. Internationalisation of this issue gave birth to new fields of cooperation between various subjects of international law, including international organisations. In this context, the United Nations and NATO would be two principal international forums aiming at peace maintenance and security.

Resolution 1540 adopted ten years ago still serves as an imperative that requires all states to implement measures aimed at preventing non-state actors from acquiring nuclear, chemical and biological weapons, related materials, and their means of delivery. Also, the resolution is the key document that establishes the conditions for disarmament process. The supervision of implementation of this resolution is entrusted to a wider spectrum of players, including international organisations that have more capabilities to react to the nuclear threat that is posed by certain countries that proclaim having or developing weapons of mass destruction.

It is worth mentioning that the topicality of this article has not been previously discussed by scholars. The author refers to the scholars, such as Rita GrossmanVermaas, Janka Oertel, Joachim Koops and others, that aim to explore the link between terrorism, disarmament and the role of international organisations, but not directly mutual cooperation between both organisations. Despite limited literature resources available due to sensitivity of this issue and absence of scholars writing on this subject, the author of the article explores the bridge building possibilities between NATO and the UN in the light of fight of nuclear terrorism. The author of the article aims to raise the question why two international organisations working in the same field but from different angles have chosen to go on their own.

In order to develop the holistic approach to the actual link of both organizations obligations, the article will discuss the role of the United Nations and the approach

1 IAEA Nuclear Security Achievements 2002-2011 [interactive]. [acessed on 2014-03-09]. $<$ http://www.iaea.org/inis/collection/NCLCollectionStore/_Public/43/038/43038436.pdf>. 
to the nuclear terrorism and the NATO support to implementation of the Resolution 1540 and areas of mutual co-operation. The structure of this article consists of several parts: the first part reveals the United Nations role to implement measures against terrorism, the second part discloses doctrinal importance of regional organisations in support of the Resolution 1540 and the third part deals with NATO support towards implementation of the Resolution 1540.

With a view to this article and revealing the research topic, various theoretical and empirical research models have been used, including logical and systematic analysis models, analysis of documents and comparative model. Historical, teleological and descriptive models have been employed as auxiliary ones.

\section{The UN Role in Fight against Terrorism}

Defining the UN role in combat against the terrorism, the former UN Secretary General Kofi Annan expressed the view that the UN system has to make contribution in all the relevant areas - from promoting the rule of law and effective criminal justice systems to ensuring that countries have the means to counter financing of terrorism; from strengthening capacity to prevent nuclear, biological, chemical or radiological materials from falling into hands of terrorists, to improving the ability of countries to provide assistance and support for victims and their families ${ }^{2}$. The need to secure that nuclear, chemical or biological weapons would not fall in the hands of terrorists and fear that those weapons may be used for malicious purposes indicated the adoption of the legal framework that would pave the path for Weapons of Mass Destruction (hereinafter - WMD) control mechanism.

To the extent new initiatives were proposed regarding WMD, they have tended to focus to specific countries, including Iran, Iraq, Libya and North Korea, or on initiatives against terroristic threats among those initiatives the 2003 Proliferation Security Initiative (PSI) and the UN SC Resolution 1540 were introduced. Being a separate document, but also a reflection of new initiatives, PSI gathered a coalition of states that have agreed to use their national resources, including force if necessary, to interdict and seize international shipments of goods believed to be illegally destined for use in WMD programmes. While the number of states participating in the PSI has expanded considerably since 2003, the Initiative has also generated criticism over issues relating to its consistency with international law, its lack of transparency and other concerns ${ }^{3}$. By the same token, the UN SC Resolution 1540 that will be explicitly

2 Secretary-General's address to the General Assembly on the launch of "Uniting against Terrorism: Recommendations for a Global Counter-Terrorism Strategy" [interactive]. [accessed on 2014-01-16]. <http://www.un.org/sg/statements/index.asp?nid=2010 > .

3 Blix Report on Weapons of Terror: Freeing the World of Nuclear, Biological and Chemical Arms, p. 55 [interactive]. [accessed on 2013-05-23]. <http://www.blixassociates.com/ 
dealt with in the following chapter has become a background document to the United Nations Global Counter-Terrorism Strategy (hereinafter - the Strategy) 4

The need to bring the various counter-terrorism activities of the United Nations system into a common framework and to elaborate a comprehensive, global counterterrorism strategy was first proposed by the High-level Panel on Threats, Challenges and Change. In its report of December 2004, the Panel drew attention to the need to develop a comprehensive strategy to fight terrorism that addresses factors that facilitate terrorism and strengthens the capacity of States and the rule of law, while also promoting fundamental human rights. The Panel called on the United Nations to take a leading role in promoting such a comprehensive strategy ${ }^{5}$.

Leading up to the 2005 September Summit and using the occasion of the oneyear anniversary of the Madrid train bombings, Secretary-General Kofi Annan, acting on the recommendations of the High-level Panel, launched his proposals for a comprehensive counter-terrorism strategy in a speech in Madrid. His proposed strategy identified five key elements as basic pillars: dissuading groups from resorting to terrorism; denying terrorists the means to carry out an attack; deterring states from supporting terrorist groups; developing state capacity to prevent terrorism; and defending human rights in the context of terrorism and counter-terrorism. With the proposed elements, the Secretary-General offered a vision, for the UN system and beyond, of a comprehensive and effective approach to terrorism that allowed for preventive, as well as operational, actions and incorporated short-, mid- and longterm measures. It was a framework to help sustain the political will of Member States to maintain the fight against terrorism on the global agenda. At the same time, it was also a practical framework to effectively assist Member States in their national, regional and global counter-terrorism efforts ${ }^{6}$.

As a result of the Summit, the World Summit Outcome in 2005 released the Document that could be considered as a background for international cooperation and recognition of terrorism as a threat to the international peace and security according to the UN Charter ${ }^{7}$. The leaders of the world then released the statement urging

DB17616E-46A8-435F-A71C-33FB15FD94CB/FinalDownload/DownloadId-E0D8CB0579 BEEC2AE099B4FCD9757A53/DB17616E-46A8-435F-A71C-33FB15FD94CB/wp-content/ uploads/2011/02/Weapons_of_Terror.pdf>.

4 Global Counter-Terrorism Strategy - UN Action to Counter Terrorism [interactive]. [accessed on 2013-12-12]. <http://www.un.org/en/terrorism/strategy-counter-terrorism.shtm>.

5 United Nations Action to Counter Terrorism. United Nations Homepage [interactive]. [accessed on 2013-12-12]. <http://www.un.org/en/terrorism/>.

$6 \quad$ Ibid.

7 The UN Security Council has acknowledged that the acts of terrorism constitute the threat to peace and security in numerous resolutions, such as 1267 (1999) of 15 October 1999, 1373 (2001) of 28 September 2001, 1535 (2004) of 26 March 2004, 1540 (2004) of 28 April 2004, 1566 (2004) of 8 October 2004, and 1617 (2005) of 29 July 2005, the declaration annexed to its resolution 1456 (2003) of 20 January 2003. This list is only exemplary. 
to fight terrorism in conformity with international law, including the Charter and relevant international conventions and protocols, also jointly condemned terrorism in all its forms and manifestations, as it constitutes one of the most serious threats to international peace and security and acknowledged the important role played by the United Nations in combating terrorism. The signatories of the document stressed vital contribution of regional and bilateral cooperation, particularly at the practical level of law enforcement cooperation and technical exchange. The Document reflected standing invitation by the Heads of the States addressed to the international community, including the United Nations, to assist States in building national and regional capacity to combat terrorism ${ }^{8}$.

Using the Secretary-General's recommendations as a basis for discussions, on 11 May 2006, Member States began consultations on formulating this Strategy in line with the commitment they made at the 2005 September Summit. The Strategy, in the form of a General Assembly (hereinafter - General Assembly or GA) resolution and an annexed Plan of Action (A/RES/60/288), has become a unique global instrument that will enhance national, regional and international efforts to counter terrorism. Also, it was the first time that all Member States have agreed to a common strategic approach to fight terrorism, not only sending a clear message that terrorism is unacceptable in all its forms and manifestation, but also resolving to take practical steps individually and collectively to prevent and combat it. Those practical steps include a wide array of measures ranging from strengthening state capacity to counter terrorist threats to better coordinating United Nations system's counter-terrorism activities. The Strategy is intended to promote comprehensive, coordinated and consistent responses at the national, regional and international levels, to counter terrorism, which also takes into account the conditions conducive to the spread of terrorism. Within its mandate acting with regard to the implementation of this Strategy, the Member States were urged to ratify the Convention of Nuclear Terrorism and also provided the recommendation to cooperate among various bodies of the UN system, namely the United Nations Counter Terrorism Committee ${ }^{9}$. With the intention of the Secretary-General, the states were also called to institutionalize, within existing resources, the United Nations Counter-Terrorism Implementation Task Force within the Secretariat ${ }^{10}$. The adoption of the Strategy fulfilled the commitment

8 Excerpts from the 2005 World Summit Outcome Document [interactive]. [accessed on 201401-16]. <http://www.un.org/en/terrorism/strategy/world-summit-outcome.shtml>.

9 Guided by Security Council resolutions 1373 (2001) and 1624 (2005), the CTC works to bolster the ability of United Nations Member States to prevent terrorist acts both within their borders and across regions. It was established in the wake of the 11 September terrorist attacks in the United States. The CTC is assisted by the Counter-Terrorism Committee Executive Directorate (CTED), which carries out the policy decisions of the Committee, conducts expert assessments of each Member State and facilitates counter-terrorism technical assistance to countries.

10 While the primary responsibility for the implementation of the Global Strategy rests with Member States, the CTITF ensures that the UN system is attuned to the needs of Member 
made by world leaders at the 2005 September Summit and builds on many of the elements proposed by the Secretary-General in his report of 2 May, 2006, entitled "Uniting against Terrorism: Recommendations for a Global Counter-Terrorism Strategy"1. While addressing to the General Assembly on the launch of "Uniting against Terrorism: Recommendations for a Global Counter-Terrorism Strategy (hereinafter - Strategy)", Kofi Annan said that it is a prerequisite to every aspect of any effective counter-terrorism strategy.

Working hand in hand, the United Nations and individual states contributed to the prevention of terrorism primarily through the adoption of multiple international documents from counter-terrorism conventions and protocols to Security Council resolutions 1267-1988/1989 (Al Qaida/Taliban Sanction regime). However, the ground document giving the legacy to combat nuclear terrorism is considered to be the Resolution $1540^{12}$ adopted by the UN Security Council ${ }^{13}$.

\subsection{United Nations Resolution 1540}

United Nations Security Council Resolution 1540 (2004) is one in the series of measures taken to address threats to the political and social order deriving from access to, or use of, weapons of mass destruction related materials and means of delivery. It is distinct from the existing treaty - based on non-proliferation/arms control regimes for example, the treaty on Non-Proliferation of Nuclear Weapons, the Convention on the Prohibition of the Development, Production, Stockpiling and Use of Chemical Weapons and on Their Destruction, and the Convention on the Prohibition of the Development, Production and Stockpiling of Bacteriological (Biological) and Toxin Weapons and Their Destruction - that govern the behavior of States Party to those treaties in several respects: it covers all WMD and it reaches beyond the state and focuses explicitly on the risk that non-state actors, in particular organisations bent on undermining or supplanting civil society, might acquire, develop, traffic or use nuclear, chemical and biological weapons and their means of delivery ${ }^{14}$. It also goes

States, to provide them with the necessary policy support and spread in-depth knowledge of the Strategy and, wherever necessary, expedite delivery of technical assistance. For further information, see: <http://www.un.org/en/terrorism/ctitf/index.shtml >.

11 Global Counter-Terrorism Strategy - UN Action to Counter Terrorism [interactive]. [accessed on 2013-12-12]. <http://www.un.org/en/terrorism/strategy-counter-terrorism.shtm>.

12 Blix Report on Weapons of Terror: Freeing the World of Nuclear, Biological and Chemical Arms, supra note 3.

13 The Security Council is the only institution in the world that has the legal authority to examine - and if there is a need to be harmonised, supplemented and enforced - the many efforts made by international community to counter and reduce the threats posed by weapons of mass destruction.

14 Security Council resolution, UN document S/RES/1540, 28 April 2004. 
beyond the existing anti-terrorism conventions that collectively impose similar though less comprehensive obligations on convention parties in that being adopted under Chapter VII of the UN Charter, the resolution is binding on all Member States of the United Nations ${ }^{15}$.

Historically, this resolution was introduced by the President of the United States of America (hereinafter - the USA) G.W. Bush, who addressed to international community in 2003, urging to cooperate in preventing the proliferation of WMD. The resolution was unanimously adopted in 2004, establishing for the first time binding obligations on all UN Member States under Chapter VII of the UN Charter to take and enforce effective measures against the proliferation of WMD, their means of delivery and related materials. Resolution 1540, if fully implemented, aims to ensure that no State or non-State actor is a source or beneficiary of WMD proliferation ${ }^{16}$. Carrying in general a positive pattern, the adoption of Resolution 1540 also evoked some discussions concerning the obligations of the states towards nuclear disarmament and non-proliferation. Firstly, Resolution 1540 illustrated the potential of the UN Security Council to bring about rules that are mandatory for the entire world community. It is fair to mention that growing dissatisfaction of states and experts expressed their view that this responsibility, if it is to be accepted by the world community of nations, must be exercised not by a small group dominated by P5 (USA, Russian Federation, United Kingdom, France and China), but in a broad consultation with and for the benefit of the whole UN membership ${ }^{17}$. Secondly, certain countries expressed their concern that this resolution is ambiguous in the sense that nuclear weapon states (hereinafter - NWS) are reluctant to proceed with nuclear disarmament. The non-nuclear states highlighted their dissatisfaction that the USA and other NWS were doing little to implement obligations to eliminate their

15 Scheinman, L. (ed.). Implementing Resolution 1540: The Role of Regional Organisations. Geneva: United Nations Institute for Disarmament Research, 2008, p. 8.

16 All states have three primary obligations under UNSCR 1540 relating to such items: to prohibit support to non-State actors seeking such items; to adopt and enforce effective laws prohibiting the proliferation of such items to non-State actors and prohibiting assisting or financing such proliferation; and to take and enforce effective measures to control these items, in order to prevent their proliferation, as well as to control the provision of funds and services that contribute to proliferation. If implemented successfully, each state's actions will significantly strengthen the international standards relating to the export of sensitive items and support for proliferators (including financing) and ensure that non-state actors, including terrorist and black-market networks, do not gain access to chemical, nuclear or biological weapons, their means of delivery or related materials. For further information, visit the US Department of State: <http://www.state.gov/t/isn/c18943.htm>.

17 Oosthuiyen, G.; Wilmhurst, E. Terrorism and Weapons of Mass Destruction: United Nations Security Council Resolution 1540. Chatham House, Briefing Paper BP 04/01, September, 2004, p. 6. Also, it must be noted that this initiative is also linked with the long awaited reform of the Security Council, where already for some decades certain states are expressing the need to review the structure and membership that was established more than half a century ago. 
own stockpiles. Brazil and other non-nuclear weapon states particularly denoted that while this resolution is limited to the question of non-proliferation, at the same time disarmament must be pursued in good faith and be more encouraged ${ }^{18}$.

Despite the expressed concerns, Resolution 1540 may be considered as a significant development, since it established a mandatory requirement for all states to refrain from providing any form of support to non-state actors in obtaining WMD. It also mandated them to adopt domestic legislation to implement this obligation. More importantly, it required states to establish national controls to prevent proliferation of WMD and their means of delivery, to secure nuclear facilities, disease surveillance, to ensure border security, to take counter-terrorism measures, counter-narcotics, to prepare for natural disasters, to establish exports control regime. As Resolution 1540 established certain sanctions, the sanctions obligations provide concrete examples, as well as a greater definition and specificity to those 1540 requirements. This synergy between the sanctions resolutions and Resolution 1540 provides an opportunity for states implementing their 1540 obligations to draw upon a series of UN-mandated "best practices" for preventing the spread of WMD as they apply to internationally recognized proliferation concerns. By employing such proliferation controls against specific proliferators, states can gain both legislative and enforcement experience implementing these types of measures, which can then be applied broadly as part of a more developed national nonproliferation system. Although the UN sanctions on Iran and North Korea are international mandates, the aim of using their specific proliferation controls as 1540 stepping stones is not intended to inform 1540 implementation for countries which still face serious capacity-building challenges. Rather, it is a way for states, which have already established baseline measures implementing 1540, to move to the "appropriate effective" controls envisioned in the Resolution ${ }^{19}$.

The obligatory nature of the Resolution raises the question of implementation. This is, for many states, a daunting task. As noted in an early analysis of the resolution, "This is especially true for many of the world's developing states, some of which, even if they have the will to [implement the resolution], lack of resources. States particularly affected are those which are not already parties to the relevant WMD treaties and do not therefore already have the appropriate measures in place-and those which although parties, have not fully implemented their obligations" ${ }^{20}$. For those reasons, regional and universal international organisations may be used as a tool to ensure support towards implementation of the Resolution 1540.

18 Blix Report on Weapons of Terror: Freeing the World of Nuclear, Biological and Chemical Arms, supra note 3.

19 Crail, P. UNSC Resolutions on Iran and North Korea as 1540 Stepping Stones [interactive]. [accessed on 2014-01-16]. <http://www.stanleyfoundation.org/publications/working_papers/ Crail1540Abstract.pdf>. 


\section{Regional Contribution to the Implementation of Resolution 1540}

Primarily focusing on the national obligations, the Strategy implies for the need of international cooperation. Sources of support for meeting the objectives of 1540 include self-help, bilateral assistance, assistance from specialized international organisations, such as the International Civil Aviation Organization, the World Customs Organization, the International Criminal Police Organization, the International Atomic Energy Agency, the Organization for the Prohibition of Chemical Weapons, the World Health Organization, etc., multilateral organisations, such as OSCE in Europe, non-governmental organisations, such as the Stockholm International Peace Research Institute, regional and sub-regional organisations ${ }^{21}$.

The follow-up documents of the Strategy encouraged all relevant international, regional and sub-regional organizations and forums involved in the fight against terrorism to cooperate with the United Nations system and Member States in supporting the Strategy and repeatedly stressed recognition of the role of the regional organizations, structures and strategies in combating terrorism, encouraging them to consider using best practices developed by other regions in their fight against terrorism ${ }^{22}$.

Regional and sub-regional organisations play a very important role in implementing the Resolution 1540, as it was the call from the side of the SecretaryGeneral, Kofi Annan, who noted in his report of July 2006 to the Security Council and General Assembly on cooperation between regional and other organisations, regional and sub-regional institutions have over time become accepted and important partners in assisting the United Nations, and other international institutions in combating threats to peace and security. More specifically, taking note of efforts to prevent access by non-state actors to WMD-related materials and technology, "including in the context of the implementation of Security Council resolutions 1540 (2004) and 1673(2006)", Annan asserted that "further progress can be achieved through United Nations interaction with regional and other intergovernmental organisations (...) to strengthen States' national capacity to implement their national obligations" under those resolutions.

Today, as Lawrence Scheinman denotes, regional and sub-regional organisations are engaged in addressing problems, such as cross-border crime, the threat from terrorism and the proliferation of small arms and light weapons. There are clear linkages between the issues and the concerns at the heart of the Resolution 1540 .

21 Scheinman, L. (ed.), supra note 15.

22 United Nations Resolution No. A/RES/66/282. The United Nations Global Counter Terrorism Strategy Review [interactive]. [accessed on 2013-12-12]. <http://www.un.org/en/terrorism/ strategy-counter-terrorism.shtm>. 
Many of the measures necessary to meet the threat posed by WMD are relevant to more conventional challenges to national security, and regional organisations can help to ensure that the steps taken by their members are compatible, effective and mutually reinforcing ${ }^{23}$.

Second, regional and sub-regional organisations tend to have a high degree of political legitimacy and enjoy a high level of confidence among their members. These organisations consist of states that have voluntarily joined together on the basis of shared values, interests, history, experience and objectives, thus offering a greater prospect of achieving agreement and consistency regarding how to address, implement and sustain a mandate that is binding on them all. It should be in the interest of these organisations that none of their members turn out to be a weak link in the regional or global chain aimed at addressing the threat of non-state actor gaining access to WMD, which if used would have security implications from which no state or region could escape ${ }^{24}$.

Lastly, related consideration is that regional organization can play an important role in achieving a common understanding and interpretation of steps necessary to take to ensure that their members work together to close gaps in 1540 implementation and remedy inconsistencies that, it left unchecked, could undermine the common good of the Member States and broader international community. In particular, regional and sub-regional organisations can assist members in identifying needs, capacity-building, resource assistance, cost sharing and the like, and in assuring that actors taken by their members are mutually reinforcing. They are in a stronger position than global institutions to assess how effectively the measures taken by their members are being implemented, and to take initiative to help remedy deficiencies ${ }^{25}$.

Open call for relevant regional and sub-regional organizations to create or strengthen counter-terrorism mechanisms or centers left open doors for NATO to assist the UN in the global fight against terrorism. While other organizations, in particular the Organisation for Security and Co-operation in Europe, are involved in substantial ways in assisting states - particularly their members and partners in meeting the objectives of the Resolution 1540, in so doing help to set standards to which others should adhere, NATO with all its capacities stay somewhere in the shadow as an invisible but a very powerful partner of the United Nations and a watchman waiting to be called out for help. As NATO Secretary General de Hoop Scheffer stated in his statement in relation to multilateral engagement, "If you ask for help, we can help and we will help."

Ibid. 


\section{North Atlantic Treaty Organization - Unlikable Partner or Forgotten Friend?}

International practice has proved that the gap between hard security (proliferation) and soft security (international development and capacity building) objectives is rarely bridged effectively. As scholar Rita Grossman-Vermaas points out, the problem is that the existing non-proliferation, capacity building and global development norms, treaties, and national strategies are a patchwork of measures often operating in near isolation. Would-be proliferators can exploit this lack of mutual support across national and functional boundaries. In short, the gap between hard security (proliferation) and soft security (international development and capacity building) objectives is rarely bridged effectively. So an immediate challenge is to coordinate better the existing tools to limit states' ability to proliferate ${ }^{26}$.

NATO-UN cooperation has so far been characterized by selective case-by-case collaboration and rather rhetorical than actual commitment to collaboration. Since NATO-UN cooperation has started to intensify fairly recently, an improvement of inter-organizational dialogue can be anticipated. Successful cooperation on case-bycase basis does not necessarily militate against a more institutionalized framework between NATO and the UN. But, as Koops states, "[...] instead of insisting too much on strict hierarchies and clearly defined functional divisions of labor, the creation of less formal but nevertheless guiding memoranda of understanding, [...] between autonomous international organizations would be an important step towards furthering coordination and collaboration" 27 .

Similarly, international cooperation between NATO and the UN was not always harmonised. On the contrary, two organizations seemed to keep certain distance between each other since NATO and the UN have always had separate agendas and were rarely seen as partners in the international arena. Cooperation between NATO and the UN began to intensify in the early 1990s and has been controversial ever since. As the 1999 air-strikes in Yugoslavia have shown, there are obvious pitfalls in the coexistence and collaboration between the major agent for peacekeeping (the UN) and the most significant provider of military power (NATO) ${ }^{28}$. NATO cooperation with the UN in combat against terrorism was never explicitly addressed

26 Grossman-Vermaas, R. Proliferation and Development - Exposing the Link. NATO Review [interactive]. [accessed on 2014-01-03]. <www.nato.int/docu/review/2007/issue3/english/art3. html>.

27 Koops, J. Towards Effective and Integrative Inter-Organizationalism. Brockmann, KathrinHauck, H.; Bastian-Reigeluth, S. (eds.). From Conflict to Regional Stability: Linking Security and Development. Berlin: Forschungsinstitut der Deutschen Gesellschaft für Auswärtige Politik, 2008, p. 19-27.

28 Oertel, J. The United Nations and NATO [interactive]. [accessed on 2013-11-30]. < voltairenet. net/IMG/.../Janka_Oertel_Paper_ACUNS_Conference.pdf > . 
to NATO in the earlier speeches of the Secretary General of the UN. Back in 2005, NATO Secretary General Jaap de Hoop Scheffer proposed a framework agreement concerning NATO-UN cooperation, including a joint declaration by both Secretary Generals. Previously UN Secretary General's High-level Panel on Threats, Challenges and Change explicitly referred to NATO-UN cooperation, regarding the Alliance's specific qualifications and stated that "[i]n the case of NATO, there may also be a constructive role for it to play in assisting in the training and equipping of less well-resourced regional organizations and States." However, in his follow-up report "In Larger Freedom", the UN Secretary General Kofi Annan also highlighted the importance of formalized cooperation with regional organizations and other security institutions, without particular mentioning of $\mathrm{NATO}^{29}$. This (presumably) accidental omission could be explained through the membership prism. All NATO Member States are also UN Member States, which resume certain international responsibilities, particularly when the fight against nuclear terrorism was always accompanied by multiple efforts put by individual states or group initiatives. As a result of common efforts to contribute to the implementation of the 1540 resolution, the states engaged themselves in several regimes aiming at global non-proliferation efforts, such as the previously discussed PSI and the G8 Global Partnership against the Spread of Weapons and Materials of Mass Destruction.

As of the beginning of a mission called Operation Active Endevour in 2004, NATO has started to refer to its active involvement into anti-terroristic activities. In the light of the Resolution 1540 and counter-terrorism measures, NATO had an opportunity to play a role and started doing so in development effort operations, such as in Afghanistan ${ }^{30}$ and Kosovo. With NATO's experience in defence and dialogue and its sensitivities to social and economic dimensions of security, it could be a structure which links non-proliferation and capacity-building. It is noteworthy that NATO primarily operates on the basis of three principles: a) compliance with international $\operatorname{law}^{31}$, b) non-duplication and complementarity ${ }^{32}$, and c) NATO's

29 Oertel, J. The United Nations and NATO [interactive]. [accessed on 2013-11-30]. < voltairenet. net/IMG/.../Janka_Oertel_Paper_ACUNS_Conference.pdf > .

30 While not a counter-terrorism operation, UN-mandated International Security Assistance Force represents NATO's determination to help the people of Afghanistan build a stable, secure and democratic state free from the threat of terrorism. In addition, many NATO Allies have forces involved in Operation Enduring Freedom, the ongoing US-led military counterterrorism operation, major activities of which are in Afghanistan. For further information, see: $<$ http://www.nato.int/cps/en/natolive/topics_77646.htm>.

31 In addition to the UN Charter and the UDHR, the NATO refers to the UN Global CounterTerrorism Strategy, International Conventions and Protocols against terrorism and relevant UN Resolutions provide the framework for all national and multilateral efforts to combat terrorism, including those conducted by the Alliance. For further information, see: $<\mathrm{http}: / /$ www.nato.int/nato_static/assets/pdf/pdf_topics/ct-policy-guidelines.pdf $>$.

32 NATO will avoid unnecessary duplication of existing efforts by individual nations or other International Organisations, including the UN, the EU and the OSCE. 
support to allies ${ }^{33}$. That means that NATO has no intention to duplicate the work of other international organisations, but it is able to contribute to successful implementation of the resolution by offering its capabilities. In order to contribute to the global fight against terrorism, NATO has developed Defence against Terrorism Programme, where it is believed that technology can help. This political engagement can be traced back in 2009 Comprehensive Strategic-Level Policy for Preventing the Proliferation of WMD and Defending against Chemical, Biological, Radiological and Nuclear (hereinafter - CBRN) Threats, endorsed at the 2009 Strasbourg-Kehl Summit and NATO's Strategic Concept, endorsed at the 2010 Lisbon Summit, which reaffirmed the Alliance's determination to ensure that NATO has the full range of capabilities necessary to deter and defend against any threat to the safety and security of the Alliance populations ${ }^{34}$.

The progress in cooperation seems to be on the way. The latest Resolution A/ Res/67/99 adopted on 14 December 2012 by the General Assembly on the Measures Eliminate International Terrorism took note of recent developments and initiatives at the international and sub-regional levels to prevent and suppress international terrorism. Among other international organisations, NATO was finally mentioned. This reference to NATO probably could be interpreted as recognition of need of NATO potential and capabilities in implementing Resolution 1540 for the following reasons. Firstly, NATO is a permanent transatlantic consultation forum, capable of transforming discussions into collective decisions and action. Secondly, NATO has at its disposal unique military and civilian capabilities that can contribute to fighting terrorism or managing the consequences of an attack. Thirdly, NATO cooperates as part of a very large network of partnerships involving other states and international organisations ${ }^{35}$.

It is needless to say that NATO has become a very important player in counterterrorist activities since the attacks of 11 September 2001. In response to those attacks, NATO invoked Article 5 of the Washington Treaty, the Alliance's collective defence clause, for the first time in its history. Thus, upon the adoption of the Resolution 1540 and reacting to the call for uniting efforts, separate Member States of NATO as well as the Alliance itself came out with the clear intention to contribute to the successful implementation of the Resolution 1540. NATO Member States also confirmed that NATO strategic concept underscores the commitment to ensure that NATO has the full range of capabilities necessary to deter and defend against any threat to the safety of our populations and the security of our territory.

33 NATO recognizes the primary responsibility of each member to protect its own territory and civilian population.

34 Grossman-Vermaas, R., supra note 26.

35 North Atlantic Treaty Organisation Homepage [interactive]. [accessed on 2014-01-03]. $<$ http://www.nato.int/cps/en/natolive/topics_77646.htm>. 
The common institutional thinking was also reflected in NATO summit in Lisbon in 2010. This summit come up with the clear intention and commitment to continue to support arms control, disarmament and non-proliferation efforts and denoted the need to seek a safer world for all and create the conditions for a world without nuclear weapons in accordance with the goal of Nuclear Non-Proliferation Treaty (hereinafter - NPT). However, beyond everything and most importantly, Alliance Member States made a reference to the Resolution 1540 and called for full implementation of the Resolution 1540 and universal adherence to, and compliance with, the NPT and to the additional protocol to the International Atomic Energy Agency Safeguard Agreement. In 2010, summit meetings of Heads of State and Government in Lisbon had also universal adherence to and compliance with the NPT.

In finding the linkage of common institutional efforts between the UN and NATO, the Resolution 66/50 on NATO measures to prevent terrorists from acquiring WMD was adopted ${ }^{36}$. This Resolution has also confirmed earlier commitments undertaken by Member States and additionally reaffirmed that counter-terrorism is a key priority for NATO. The resolution has identified NATO's position and readiness to act against proliferation of WMD in one of the documents reflecting mutual areas of actions against terrorism. At present, NATO is working with affiliated UN bodies, such as the UN Counter-Terrorism Committee, its Executive Directorate and the Security Council Committee 1540. It has also established contacts with the UN on its Global Counter-Terrorism Strategy and works closely with UN agencies that play a leading role in responding to international disasters and in consequence management - the UN Office for the Coordination of Humanitarian Affairs and the Organization for the Prohibition of Chemical Weapons - as well as other organizations ${ }^{37}$.

However, there is always more room for closer cooperation between both organisations. Despite of absence of more intense institutional cooperation, NATO and the UN could be a perfect match of partners in combat against terrorism according to the Resolution 1540. The help that NATO could possibly provide to the UN would primarily consist of the contribution of all its institutional and logistic means. Among other means of NATO's contribution to the successful implementation of the Resolution 1540, the focus should lie on cooperation with partners, chemical, biological, radiological and nuclear (hereinafter-CBRN) defense capabilities and science cooperation ${ }^{38}$. NATO can also propose its help using one of those means which are currently conducted under the umbrella of NATO: a) incident management (such as protection of harbors and ports), b) network engagement, and <www.un.org/disarmament/HomePage/.../DYB2011-Part-II-web.pdf >.

37 North Atlantic Treaty Organisation Homepage, supra note 35.

38 For example, under the umbrella of NATO, a variety of mechanisms, including workshops, training courses and multi-year research and development projects, are conducted. Few examples of this cooperation are new technology for detection of "dirty bombs", treatments for nerve agent poisoning; advanced techniques for bio-weapon defence. 
c) force protection/survivability. The latter means offers a wide range of initiatives. Among other initiatives ${ }^{39}$, the detection, protection against and defeat of CBRN weapons was indicated. The aim of this measure is to prevent terrorists from using CBRN weapons, and to protect forces and populations against their effects should prevention fail.

Also, potential steps to a more institutionalized cooperation between the two organizations could consist of a more frequent interpersonal exchange as well as regular high-level consultations. Also, a permanent observer status for NATO within the UN General Assembly could link the organizations more closely together. The final introduction of the proposed framework declaration could make the relations more predictable and improve the inter-organizational dialogue ${ }^{40}$. This direction would not be something new. The flexibility to adapt for NATO to the changing environment is foreseen in NATO Treaty, which makes no specific reference to Chapter VIII of the UN Charter and thus explicitly does not qualify NATO as a Chapter VIII regional organization. The sole reference is made to Article 51 of the UN Charter, which subjects NATO's enforcement measures to the veto in the Security Council, which would have rendered its existence as a military alliance. Therefore, mandating or subcontracting NATO within the framework of UN peace operations - as recently has been the case in the Balkans and currently in Afghanistan - clearly shows NATO's evolution beyond its original alliance character towards a "security manager" in Europe and beyond ${ }^{41}$. Not only NATO has evolved past its original purpose, but the UN likewise hardly resembles its 1945 founding structure. While NATO "struggled to redefine its purpose" and moved on to crisis-management activities, the UN focused on a variety of development issues as well as a new generation of peacemaking and peacekeeping operations ${ }^{42}$. This cooperation would not mean the shift to the new level of cooperation, but rather would formalize existing relations.

39 Other means are listed as follows: reducing the vulnerability of wide-body civilian and military aircraft to man-portable air defence missiles (MANPADs); protecting harbors and ships, reducing the vulnerability of helicopters to rocket-propelled grenades (RPGs); countering improvised explosive devices (IEDs), such as car and road-side bombs, by their detection and disruption or neutralization; technologies for intelligence, reconnaissance, surveillance and target acquisition (IRSTA), with the goal of developing improved tools for early warning and identification of terrorists and their activities; explosive ordnance disposal (EOD); technologies to defend against mortar attacks; developing non-lethal capabilities.

40 Von Seherr-Thoss, B. A New Strategic Partnership? Deepening UN-NATO Relations. In: DGAP Bericht. Security in a Globalized World. Towards Regional Co-operation and Strategic Partnerships. New Faces Conference, 2006, NUPI Oslo, p. 33-42.

41 Yost, D. S. NATO and International Organizations. In: Koops, C. M. (ed.). NATO Defense College, Research Division, Forum Paper Series. Rome, 2007, p. 31-64 [also interactive]. <http:// www.ndc.nato.int/download/publications/fp_03.pdf.>.

42 Tardy, T. The Inherent Difficulties of Inter-institutional Cooperation in Fighting Terrorism. In: Boulden, J.; Weiss, T. G. (eds.). Terrorism and the UN. Before and After September 11. Bloomington and Indianapolis: 2004, p. 120. 


\section{Conclusions}

Indeed, the Resolution 1540 has become the cornerstone document that imposes dual obligations to the members of the United Nations. The first obligation is to adopt legislation to prevent the proliferation of nuclear, chemical and biological weapons, and their means of delivery. Another part of obligations requires the Member States to establish appropriate domestic controls over related materials to prevent their illicit trafficking. While states are primarily targeted by the Resolution 1540, the highest ranking officials of the United Nations and the IAEA rather refer to other organisations than NATO for aid and expertise to prevent nuclear smuggling and nuclear terrorism. The lack of any sort of cooperation between both organisations imposes the thought that the UN is avoiding military partnership with the Alliance that some UN members are considering as hostile and which will not renounce the use of nuclear weapons and nonetheless will maintain an appropriate mix of conventional, nuclear, and missile defence forces. This thought is supported by the fact that until recently NATO has not not even explicitly mentioned the official speeches of the Secretary General of the United Nations regardless its expertise in combating terrorism and despite its potential to propose its unique military and civilian capabilities, incident management, network engagement, force protection, also logistic support in addition to the one that is provided to the UN by its individual members.

Sadly, the regional contribution of NATO is underestimated and not fully used. In the daylight of the changing context of NATO and UN activities that are involving NATO shifting the spot to crisis - management activities on the one hand and developing UN interest in a new generation of peacemaking and peacekeeping operations on the other one. Doctrinal proposals to enhance UN-NATO cooperation that would formalise existing relations consist of regular high-level consultations, proposal to grant NATO a permanent observer status within the UN General Assembly and final introduction of the proposed framework declaration. This proposal could be considered only if the Alliance is invited for formal talks with the intention of long term cooperation, which the UN seemingly does not seek. On the other hand, in authors' view, the bilateral document that would pave the path for cooperation would be highly desirable for the future.

Ultimately, in authors' view, the consideration of establishment of the working group to discuss the use of NATO's contribution to the successful implementation of the Resolution 1540, particularly NATO's science cooperation between the UN and NATO, could eventually lead to increased capabilities to fight international terrorism that carries a pattern of use of nuclear, chemical, bacteriological or biological weapons. The working group could become the nutshell of the further cooperation in the field of nuclear terrorism and could support efforts of individual states and other international organisations to contribute to the international peace and security according to the UN Charter. 


\section{References}

2011 Disarmament Yearbook - The United Nations [interactive]. [accessed on 2013-12-04]. <www.un.org/disarmament/HomePage/.../DYB2011-Part-IIweb.pdf $>$.

Blix Report on Weapons of Terror: Freeing the World of Nuclear, Biological and Chemical Arms [interactive]. [accessed on 2013-05-23]. <http:// www.blixassociates.com/DB17616E46A8-435F-A71C-33FB15FD94CB/ FinalDownload/DownloadId-E0 D 8CB 0579 BEEC2AE0 99B 4FCD 9757A53/DB17616E-46A8-435FA71C-33FB15FD94CB/wp-content/ uploads/2011/02/Weapons_of_Terror. pdf $>$.

Crail, P. UNSC Resolutions on Iran and North Korea as 1540 Stepping Stones [interactive]. [accessed on 2014-0116]. <http://www.stanleyfoundation. org/publications/working_papers/ Crail1540Abstract.pdf $>$.

Excerpts from the 2005 World Summit Outcome Document [interactive]. [accessed on 2014-01-16]. <http:// www.un.org/en/terrorism/strategy/ world-summit-outcome.shtml>.

Final Report of the Working Group on Addressing Radicalization and Extremism that Lead to Terrorism [interactive]. [accessed on 2013-1115]. <www.un.org/en/terrorism/pdfs/ radicalization.pdf $>$.

General Assembly Resolution A/ RES/64/297 on the Global CounterTerrorism Strategy (2010) [interactive]. [accessed 2013-11-15]. <http://www.un.org/en/terrorism/>.
Grossman-Vermaas, R. Proliferation and Development - Exposing the Link. NATO Review [interactive]. [accessed on 2014-01-03]. <www.nato.int/docu/ review/2007/issue3/english/art3. html>.

IAEA Nuclear Security Achievements 2002-2011 [interactive]. [acessed on 2014-03-09]. <http://www.iaea.org/ inis/collection/NCLCollectionStore/_ Public/43/038/43038436.pdf>.

International Convention for the Suppression of Acts of Nuclear Terrorism [interactive]. [accessed on 2013-10-03]. <www.un.org/en/sc/ctc/ docs/conventions/Conv13.pdf $>$.

Koops, J. Towards Effective and Integrative Inter-Organizationalism. Brockmann, K.-H.; Bastian., H.; Reigeluth, S. (eds.). From Conflict to Regional Stability: Linking Security and Development. Berlin: Forschungsinstitut der Deutschen Gesellschaft für Auswärtige Politik, 2008.

NATO Strategic Concept 2010 [interactive]. [accessed on 2014-01-03]. <http://www.nato.int/cps/en/ natolive/ topics_82705.htm $>$.

NATO Summit Lisbon, November 20, 2010. Statement issued by the Heads of State and Government [interactive]. [accessed on 2013-1111]. <http://www.ambafrance-us.org/ spip.php?article1968e >.

NATO's Policy Guidelines on CounterTerrorism [interactive]. [accessed on 2014-01-03]. <http://www.nato.int/ nato_static/assets/pdf/pdf_topics/ctpolicy-guidelines.pdf $>$. 
North Atlantic Treaty Organisation Homepage [interactive]. [accessed on 2014-01-03]. <http://www.nato.int/ cps/en/natolive/topics_77646.htm $>$.

Oertel, J. The United Nations and NATO [interactive]. [accessed on 2013-1130]. <voltairenet.net/IMG/.../Janka_ Oertel_Paper_ACUNS_Conference. pdf $>$.

Oosthuiyen, G.; Wilmhurst, E. Terrorism and Weapons of Mass Destruction: United Nations Security Council Resolution 1540. Chatham House, Briefing Paper BP 04/01, September, 2004.

Scheinman, L. (ed.). Implementing Resolution 1540: The Role of Regional Organisations. Geneva: United Nations Institute for Disarmament Research, 2008.

Secretary-General's Address to the General Assembly on the Launch of "Uniting against Terrorism: Recommendations for a Global Counter-Terrorism Strategy" [interactive]. [accessed on
2014-01-16]. <http://www.un.org/sg/ statements/index.asp?nid=2010 $>$.

Tardy, T. The Inherent Difficulties of Inter-institutional Cooperation in Fighting Terrorism. In: Boulden, J.; Weiss, T. G. (eds.). Terrorism and the UN. Before and After September 11. Bloomington and Indianapolis, 2004.

United Nations Action to Counter Terrorism. United Nations Homepage [interactive]. [accessed on 2013-12-12]. $<$ http://www.un.org/en/terrorism/>.

Von Seherr-Thoss, B. A New Strategic Partnership? Deepening UN-NATO Relations. In: DGAP Bericht. Security in a Globalized World. Towards Regional Co-operation and Strategic Partnerships. New Faces Conference 2006, NUPI Oslo.

Yost, D. S. NATO and International Organizations. In: Koops, C. M. (ed.). NATO Defense College, Research Division, Forum Paper Series. Rome, $2007<$ http://www.ndc.nato.int/ download/publications/fp_03.pdf >.

\title{
JTO IR NATO BENDRADARBIAVIMAS İGYVENDINANT JUNGTINIŲ TAUTŲ SAUGUMO TARYBOS REZOLIUCIJĄ 1540
}

\author{
Dalia Vitkauskaitè-Meurice \\ Mykolo Romerio universitetas, Lietuva
}

Anotacija. Straipsnyje nagrinejjamos Jungtiniu Tautų Organizacijos ir Šiaurès Atlanto Sutarties organizacijos bendradarbiavimo galimybes kovojant su branduoliniu terorizmu. Išsamiai atskleidžiamos Jungtiniu Tautu Saugumo Tarybos rezoliucijos 1540 (2004) priemimo aplinkybès ir jos igyvendinimas tarptautinès teisés subjektu, tokiu kaip tarptautinés organizacijos. Straipsnio autore nagrinèja Jungtiniu Tautu ir Šiaurés Atlanto Sutarties organizacijos bendradarbiavimo ribas igyvendinant 1540 (2004) rezoliucija, kuri siekia pažaboti masinio naikinimo ginklu, galinčiu bùti pa- 
naudotais terorizmo tikslais, platinima. Straipsnis atskleidžia, kad nepaisant abieju organizaciju, kuriu tikslas yra taikos ir saugumo palaikymas regioniniu ar universaliu lygmeniu, panašumu, jų bendradarbiavimas šioje srityje igyvendinant rezoliucija 1540 (2004) nèra pakankamai išplètotas.

Reikšminiai žodžiai: Jungtinès Tautos, Šiaurès Atlanto Sutarties organizacija, terorizmas, tarptautinis bendradarbiavimas, tarptautinès organizacijos, nusiginklavimas.

\title{
THE UN-NATO COOPERATION IN IMPLEMENTING THE UNITED NATIONS SECURITY COUNCIL RESOLUTION 1540
}

\author{
Dalia Vitkauskaite-Meurice
}

Mykolas Romeris University, Lithuania

Summary. This article covers a blanket area of cooperation between two international organisations, i.e. the United Nations and the North Atlantic Treaty Organisation, that both are committed to the fight against terrorism according to the United Nations Security Council's resolution 1540. The United Nations Security Council resolution 1540 was adopted unanimously on 28 April 2004, regarding the non-proliferation of weapons of mass destruction. Being the principal reference in the fight against nuclear terrorism, the resolution 1540 establishes the obligations under Chapter VII of the United Nations Charter for all Member States to develop and enforce appropriate legal and regulatory measures against the proliferation of chemical, biological, radiological and nuclear weapons and their means of delivery, in particular, to prevent the spread of weapons of mass destruction to non-state actors. The implementation of this resolution was entrusted to individual states and to international organisations, such as the International Civil Aviation Organization, the World Customs Organization, the International Criminal Police Organization, the International Atomic Energy Agency, the Organization for the Prohibition of Chemical Weapons, the World Health Organization, etc., multilateral organisations, such as the OSCE in Europe, non-governmental organisations, such as the Stockholm International Peace Research Institute, regional and sub-regional organisations. Regional and subregional organisations play a very important role in implementing the resolution 1540, as it was the call from the side of the UN Secretary-General, who noted on cooperation between regional and other organisations, regional and sub-regional institutions have over time become accepted and important partners in assisting the United Nations, and other international institutions in combating threats to peace and security. Taking into 
consideration that NATO considers terrorism as a global threat that knows no border, nationality or religion, it could be seen as a helpful counterpart in this fight, however, the reality shows that the UN does not refer for NATO help. The author of the article explores the limits of cooperation between both organisations that are committed to the maintenance of peace and security globally or at regional level.

Keywords: United Nations, North Atlantic Treaty Organisation, terrorism, international cooperation, international organisations, disarmament.

Dalia Vitkauskaitė-Meurice, Mykolo Romerio universiteto Teisės fakulteto Tarptautinès ir Europos Sajungos teisès instituto lektorè, socialinių mokslų (teisè) daktarè. Mokslinių tyrimų kryptys: tarptautinè žmogaus teisių teisé, tarptautinè teisè.

Dalia Vitkauskaitè-Meurice, Mykolas Romeris University, Faculty of Law, International and European Union Law Institute, lecturer, doctor of social science (law). Research interests: international human rights law, international law. 